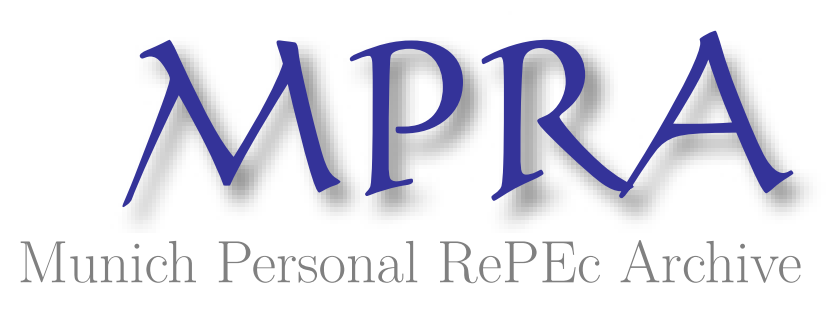

Gaps in the Theory and Practice of Islamic Economics

Al-Jarhi, Mabid

2013

Online at https://mpra.ub.uni-muenchen.de/66716/

MPRA Paper No. 66716, posted 18 Sep 2015 17:40 UTC 


\title{
GAPS IN THE THEORY AND PRACTICE OF ISLAMIC ECONOMICS
}

\author{
DR. MABID ALI AL-JARHI \\ VISITING PROF., FACULTY OF ISLAMIC STUDIES \\ HAMAD BEN KHALIFA UNIVERSITY
}

\begin{abstract}
PRELIMINARY DRAFT, NOT TO BE QUOTED WITHOUT THE PERMISSION OF THE AUTHOR
\end{abstract}

THE AUTHOR IS INDEBTED TO AN ANONYMOUS REFEREE FOR VALUABLE COMMENTS AND SUGGESTIONS. 


\section{ABSTRACT}

After a generation of non-professional writers in Islamic economics, professional economists entered the stage with an important ambition, which has been to introduce a third alternative to humanity in addition to capitalism and socialism that would answer some of the inadequacies of each. Moreover, the analysis of human (household and collective) behavior towards scarcity under the teachings of Islam was itself worth pursuing.

The intellectual effort is yet to produce significant practices of Islamic economics. The exceptions include some application of Islamic finance that raises many questions, and spotty application of Zakah and Awqaf.

The most serious challenges of Islamic finance is the rise of products of ill repute that result from determined refusal to adhere to the decisions of the International Fiqh Academy.

This paper identifies several gaps in Islamic economics and proposes ways to fill them, placing such responsibility squarely on Islamic economists. 


\section{INTRODUCTION}

The ambitions of the economists who established the field of Islamic economics in the late seventies has been to introduce to humanity a new all-encompassing economic paradigm that gradually presents itself as an additional options in the choice of economic systems. In addition, the analysis of human economic behavior under Shari'ah compliance would represent an academic curiosity that is in itself worth pursuing.

Despite many daring steps towards application, Islamic economics is still to a large measure caged in books without being applied to real-life situations. The major exception is Islamic finance. In addition, some applications of Zakah and Awqaf can be found.

Even in Islamic finance, the record of application does not have complete silver lining. Products of ill repute that are prohibited by decisions of the International Fiqh Academy dominate the Islamic finance industry in some countries.

Several gaps in Islamic economics need to be filled by both scholars and practitioners. When the count of such gaps started for the purpose of writing a keynote speech for a seminar sponsored by Aston and Dirham universities last month, it reached seven. Now, it seems to be increasing.

\section{FIRST GAP: DIVISION OF LABOR BETWEEN ECONOMISTS AND SHARI'AH SCHOLARS}

An important reason for such dilemma is that there is some disagreement regarding the nature of Islamic economics. Such disagreement has arisen during the practices of Islamic finance. Shari'ah scholars occupied a front seat in such implementation. Then, many acquired the impression in academic and professional circles that 
Shari'ah scholars are "Islamic economists." The media often introduces them as such. Considering the time and effort involved in studying economics, we cannot imagine that Shari'ah scholars would instantly turn economists, once they supervised Islamic financial transactions.

The involvement of Shari'ah scholars into Islamic finance afforded them the opportunity of rubbing shoulders with bankers. A symbiotic relationship between both parties began. Shari'ah scholars, while being accustomed in their profession to have modest earnings, found opportunities of high remuneration for their advisory services and bankers found that the seal of approval of Shari'ah scholars is worth a lot in the market. This encouraged Shari'ah scholars to keep their posture as Islamic economists and to ignore economists themselves.

In addition, Islamic finance has such a narrow scope in Islamic economics, yet it attracts disproportionate attention. The twelve Islamic finance and investment contracts can be quickly learnt by an economist. In addition, economists would have a comparative advantage over Shari'ah scholars in defining Maqassid Al-Shari'ah in the field of economics, which is something to which Shari'ah scholars pay little attention.

Shari'ah scholars, as they are totally absorbed in assessing and insuring the formal validity of contracts, sometimes with total disregard to their consequences or Ma'alaat ${ }^{1}$. They seem to be satisfied with any contract, once they find a text in the old Fiqh literature in its support. While they understand well the importance of Maqassid, they pay insufficient attention to them in practice.

As example of this is the fact that the prohibition of Reba

\footnotetext{
${ }^{1}$ For example, the author estimates that Tawarruq products represent 80 percent in Saudi Arabia and 50 percent in the UAE. Products based on debt sale dominate 60 percent of the total in Malaysia.
} 
would automatically indicate that any transaction that boils down to exchanging spot for future money at a premium should be prohibited. Yet few scholars insist that Tawarruq transactions are lawful, although their ultimate result is the trade of spot for future money at a premium.

Economists in contrast are particularly trained in assessing the consequences of actions. Their attention is always fixed towards ultimate consequences. To do otherwise would be contrary to the methodology of their discipline.

The first gap we can find in Islamic economics is the encroachment of Shari'ah scholars on the field of economics, without being true to its methodology, nor being able to learn the basics that any economist worth his/her salt must know.

We must therefore admit that Islamic economics is a branch of economics and not of Shari'ah, and Islamic finance is a branch of Islamic economics. Consequently, the tone of this discipline must be set by economists.

Economists and Shari'ah scholars must therefore agree on the division of labor. Shari'ah scholars can continue to do the job they know best, which is ascertaining formal validity of contracts, but the more important validity of purpose must be left to economists.

\section{SECOND GAP: THE ABSENCE OF AN ISLAMIC ECONOMIC SYSTEM IN REAL LIFE}

The second gap lies in the absence of a model of Islamic economics that is applied in the real world. We can find countries with various political systems that raise the flag of Islamic economics. Implementation, however, is limited to scattered applications, like some application of Zakah, Awqaf and Islamic finance with predominance of products 
of ill repute, without a coherent common denominator between them.

In contrast, there is one country that practices totalitarianism and military rule, but has made some modest advances in Islamic finance and macroeconomic policies.

At the end, we notice that we do not have an economic system that approaches the application of the Islamic paradigm. Compared to economists studying other systems, e.g., socialism and capitalism, Islamic economists find themselves at a big disadvantage. Undoubtedly, the presence of a socialist and a capitalist system has helped economists to introduce realistic and purposeful models for analysis which have later become a source of intellectual innovation.

\section{THIRD GAP: THE ABSENCE OF A GENERAL EQUILIBRIUM MODEL FOR AN ISLAMIC ECONOMY}

The third gap appeared when the paradigm of Islamic finance took a wrong detour from the very start. We concentrated on the prohibition of Reba or interest and how to provide finance in an interest-free environment. An economist would notice that Islamic finance is based on the prohibition of trading present against future money, which means that money would have a time value only when traded against non-monetary commodities.

This would require a more detailed general equilibrium model in which there is a market for trading each commodity, either spot, against deferred payment or with deferred delivery. Agios ${ }^{2}$ in such market, namely markups

\footnotetext{
${ }^{2}$ Traditionally an agio can be likened to the difference between the nominal and actual value of currency, and later to the commission taken by money changers to convert a currency into another. The word is used here to indicate differentials earned through the sale of goods or services.
} 
and rentals would have difficulty finding a balance, because of the absence of an integrated debt market and the prohibition of debt trading. Arbitrage between, e.g., the wheat and the cotton markets for deferred payments and deferred delivery is not directly obvious and has not been considered theoretically.

Add to this, the fact that we ignored the problem of term structure in such markets. Compared with conventional finance, such agios like, rates of return on Musharaka and Mudaraba, and fees on investment Wakala replace the rate of interest. Little has been said about whether their payment would have the same inefficiency effects that result from the substitution of real resources for money in transactions ${ }^{3}$.

One of the reasons for such gap in our analysis lies in the way we began in the late seventies analyzing Islamic finance in a pure profit-sharing model. Somewhere along the way some of us forgot that pure models are tools of theoretical analysis rather than paradigms. Some came up with attacks on sale finance, particularly Murabaha as not being consistent with profit and loss sharing.

Another reason is that Islamic economists have mostly been students of the Anglo Saxon School of commercial banking. Very few of us came to learn about universal banking. Being a model of pure financial intermediation between borrowers and lenders, commercial banking made the model of Islamic banking look rather impossible ${ }^{4}$.

The detour has been long and bumpy calling for speedy correction. Our perception of the paradigm of Islamic finance requires refocusing on the absence of spot-againstfuture money markets. This would lead to two inevitable

${ }^{3}$ Mabid Ali Al-Jarhi (1983)

${ }^{4}$ Mabid Ali Al-Jarhi (2003) 
consequences. First, finance must be redefined to indicate the provision of required commodities through deferred payment, deferred delivery, sale of services and usufruct, partnership (in profit or product) or investment agency. Second, banking should be redefined to include investment and trading activities. These two steps represent a good part of the revolution of Islamic economics against the received doctrine.

\section{FOURTH GAP: THE ROLE OF SHARI'AH BOARDS}

The fourth gap emanates from Islamic finance practices, which is the absolute requirement of Shari'ah boards in Islamic financial institutions. The function of Shari'ah boards is to structure Islamic financial products. This may have been necessary when Islamic finance was an infant industry. Now Islamic financial products are well defined. Most of them are considered lawful, Halal, by most Shari'ah scholars. Few are considered unlawful, which I prefer to call "products of ill repute," that include Tawarruq, debt trading, 'Eina sale and risk-trading products ${ }^{5}$. Sadly enough, in some countries products of ill repute dominate the Islamic finance market.

Placing the definitions of Islamic finance products into the banking and financial market laws would significantly reduce the need for Shari'ah boards and replace them gradually by legal experts with sufficient understanding of Shari'ah to apply such definitions ${ }^{6}$.

\section{FIFTH GAP: THE ABSENCE OF A UNIFIED AND WELL-DEFINED SHARI'AH METHODOLGY}

The fifth gap lies in the yet to be perfected methodology of

${ }^{5}$ Mabid Ali Al-Jarhi (2007).

${ }^{6}$ Mabid Ali Al-Jarhi (2012). 
Shari'ah scholars. On the one hand, they accept theoretically that giving the validity of purpose in Islamic financial contracts must take precedence to formal validity. The ultimate consequence of contracts would therefore become the acid test for its validity. On the other hand, most of their judgments are based on formal validity. Such approach appears to be similar to partial in contrast to general equilibrium analysis in economics.

This calls for a revolution in Fiqh Al-Muamalat. Since in such field, economics and Shari'ah disciplines have to be used together, Shari'ah methodology must be adjusted to give precedence to Maqassid, properly stated. Otherwise, Islamic finance will continue to be open to sharp differences, depending on whether scholars stress Maslaha, Sadd al-Altharai'e, different dosages of each, or ultimate Maqassid.

Once the methodological gap has been filled, Shari'ah boards will seize to apply ingenious ruses to mimic conventional financial products carefully dressed in Islamic garb.

\section{SIXTH GAP: CENTRAL BANKS TREATMENT OF ISLAMIC FINANCE}

The sixth gap is related to the way central banks define their relationship with Islamic banks. Central banks generally ignore the differences between Islamic and conventional banks. This raises two complications. One is that the investment activities of Islamic banks may escape legitimate scrutiny from central banks, which focus on financial soundness and pay little attention to investmentrelated activities like feasibility studies and reviews. Central banks would not like to look into such technicalities as they are outside the competence of their 
supervisory staff.

Another possibility is that central banks, unaware of the true nature of Islamic banks, and unaccustomed to universal banking, may force Islamic banks into avoiding investment activities as being incommensurate with central banks perception of banking. Islamic banks would substitute Shari'ah compliant products with other products that mimic conventional finance dressed in an Islamic garb.

The other complication lies in the fact that central banks do not wish to involve themselves into Shari'ah matters. While they provide banks with licenses to work as "Islamic banks" that are supposed to have Shari'ah-compliant activities, they would not withdraw such licenses from banks violating them by supplying conventional financial products carefully dressed to appear as Shari'ah compliant. In the first instance, central banks must regulate and properly supervise Islamic banks' investment activities. They should review investment procedures, feasibility studies and investment worthiness of Islamic banks' use of funds. Limiting supervision to the financial review of Islamic banks is by no means sufficient.

In the second instance, central banks must make their judgment about the Shari'ah compliance of Islamic banks, depending on their own methods and expertise and not just those of banks' Shari'ah boards. This can be done through external Shari'ah auditing, or simply applying the definitions of Islamic finance products mentioned in the banking and financial market laws to the actual products provided by banks. The reputation risk faced by Islamic banks has been rather serious and has not been fully eliminated by their Shari'ah boards. Such elimination would require extra actions from central banks. 
Some central banks, together with some regional and financial institutions have established the Islamic Financial Services Board to develop regulatory and supervisory standards for Islamic banks and financial institutions. The IFSB succeeded in issuing some standards, using customary procedures. However, the differences between the ISFB standards and the conventional ones often seem to be marginal. The IFSB seems to have avoided the difficult questions, especially those related to capital requirements and the governance of Shari'ah boards. In addition, most central banks which are IFSB members do not adhere to its standards anyway.

\section{SEVENTH GAP: CENTRAL BANKS APPLICATION OF CAPITAL REQUIREMENTS TO ISLAMIC BANKS}

The seventh gap is the way central banks calculate capital requirements for risk and liquidity management in Islamic banks. It is perfectly understandable to consider equity as a highly risky endeavor by conventional banks. Their liabilities are generally short term loans whose repayment is guaranteed (both principal and interest). Naturally, their assets must be equally short-term debt whose repayment is carefully guarded with collateral and other guarantees.

Islamic banks, meanwhile, have liabilities drawn from shareholders' funds and investment deposits. None of such liabilities is guaranteed debt, but rather profit sharing funds. The maturities of the funds can be extended through the proper introduction of restricted and long-term investment deposits.

Equity finance itself is an investment that entitles the bank to continuous and inexpensive monitoring. It is therefore relatively free from information asymmetry and consequently protects banks from risks of adverse selection 
and moral hazard. In contrast to being a source of exposure to high risks in conventional banking, equity finance turns out to be an important risk metigant to Islamic banks. Therefore, central banks must stop penalizing Musharaka finance through heavy capital requirements. Instead, they should instruct Islamic banks to use Mudaraba finance solely with Musharaka.

The application of Basle II AND Basle III to Islamic banks can be taken as an opportunity to reconsider a new definition of banking that combines universal banking with Islamic modes of finance. The internal liquidity and risk management systems of such banks should be customized to suit their nature. This can be an added challenge to the IFSB.

\section{EIGHTH GAP: FAULTY SUKUK}

The eighth gap is related to Islamic financial assets and Sukuk in particular. Sukuk are supposed to be Islamic financial assets that represent common undivided shares in Shari'ah-compliant real and financial assets. Sukuk therefore would be like shares in companies that represent equity investment. However, Sukuk have been entrusted to the financial engineering talents of a group of Shari'ah scholars who view them not as Islamic financial instruments but are rather "Islamic bonds" or fixed income instruments that have cleverly been made up to look Shari'ah compliant. Such perception can be traced back to the time when Islamic banks relied on British law firms in formulating contracts for international transactions, particularly syndicated finance.

The global financial crisis has succeeded in washing out the thin Shari'ah compliance paint from several issues of Sukuk. Suddenly some Sukuk appeared to be pure 
conventional loans indicating no title to any asset. The philosophy of Islamic financial engineering has been set from the beginning to issue bond-like instruments, paying no attention to the Islamic finance paradigm. Obviously, a revolution is urgently required to correct our thinking towards securitization in order to stop issuing titles to common shares in debt under the name of Sukuk. A lot of work is required in this regard. AAOIFI has issued a new statement on Sukuk which added little in correcting the ongoing practices. Perhaps the International Fiqh Academy should consider issuing its Sukuk standard to fill such gap. The Academy has made a valuable contribution by recently by issuing one resolution on Sukuk in its $19^{\text {th }}$ Meeting (Sharjah, 2009) and another one in its $20^{\text {th }}$ Meeting (Algeria, 2012) ${ }^{7}$.

\section{NINTH GAP: THE HIATUS BETWEEN MONETARY POLICY AND ISLAMIC FINANCE.}

The ninth gap is the absence of any measurable link between monetary policy and Islamic finance. Financial instruments issued by monetary and financial authorities are mostly conventional. Changes in the monetary base or high-powered money largely depend on the debt money markets rather than the investment markets.

The mere process of issuing money and the control of money supply in a conventional economy is debt-based. The central bank issues money in order to lend it to government and banks. Islamic economics offer an alternative approach that ties issuing money with investment ${ }^{8}$. Such approach is based on two pillars. First, the central bank must attune monetary growth to economic growth, and not to the requirements of financing

${ }^{7}$ International Islamic Fiqh Academy (2009, 2012).

${ }^{8}$ Mabid Al-Jarhi (1983). 
government budget deficit. Second. All money issued must be invested through banks as investment deposits. Profits would ultimately help in financing government budget.

\section{TENTH GAP: SHYNESS FROM USING MORAL VALUES}

Some Islamic economists may feel that their discipline is not value free, while economics is a positive science. Being anxious to mimic physics, economists heavily use mathematics and statistics to develop and test their theories. Along the way they forget that their unit of analysis is human. Human qualities include believing and practicing certain moral values. Homo Economicus in conventional economics is assumed to be a self-interested person, which may imply utility and wealth maximization. This is the most important moral judgment in economics, yet not sufficiently obvious to others.

Islamic economists must therefore place economics in the right perspective. It is a social science whose unit of analysis is human which has its attitudes to the economic phenomenon of scarcity. Naturally, Islamic economics can make its how assumptions about its unit of analysis. They may even define a Homo Islamicus who abides by Shari'ah in his or her economic behavior. They may also continue to use mathematics and statistics for developing and testing theories, without ignoring that the claim of economics being a positive science is just a mirage.

\section{HOW TO FILL THE GAPS}

Gaps like these must be filled through the correction of our understanding, the reorientation of our analysis, and the straightening of our applications. This requires extra efforts from Shari'ah specialists, economists, finance 
specialists and practitioners. It is my sincere belief that Islamic finance, when properly perceived and correctly applied will produce a new economic order that benefits humanity. It therefore deserves proper perception and correct application.

The responsibility for filling the gaps in the field of Islamic economics lies squarely on economists' shoulders. Currently, and after the first generation of Islamic economists, we need a second generation that has a strong command of the tools of analysis as well as a good understanding of Fiqh Al-Muamalat.

The second generation must start with learning the contributions of the first generation and build upon them in order to present further contributions.

The last step requires a selective approach to research topics. The new generation must avoid topics which are too general or concern some limited applications.

Articles regarding environment, sustainable growth and other topics in economic development usually have very little added value. Other non-analytical articles about Zakah and Awqaf should also be shunned away.

Some of the possible solutions are:

First, we need to provide more scholarships to economics students to write $\mathrm{PhD}$ dissertations in Islamic economics. The scholarship must include paying for studying Shari'ah in the area of Maqassid, policies and Muamalat.

Second, it is about time to publish and distribute some of the contributions of the first generation. For example, the author's article entitled: towards a monetary and financial system for an interest-free economy deserves attention. None of the younger generation has shown familiarity with it nor built upon it any further analysis. The article has 
seen further extensions by the author which have not been published yet.

Third, appointment of some members of the first generation as professors to teach their own thought and perceptions of Islamic economics to graduate students would help is passing the flag to the next generation.

Fourth, we must provide assistance to the countries of the Arab Spring, which desire to introduce Islamic finance, in order to enable them to build up a credible applied model and put it to practice gradually. This will eventually provide theoreticians with real-life experiments. 


\section{REFERENCES}

1. Al-Jarhi, Mabid Ali (1976), the relative Efficiency of Interest-Free Monetary Economies, the Fiat-Money Case, Institute of National Planning, Cairo, April. Also in: Khurshid Ahmad, ed., Studies in Islamic Economics, Center for Research in Islamic Economics, Jeddah and the Islamic Foundation, London, 1980; Mohsin Khan and Abbas Mirakhor, eds., Theoretical Studies in Islamic Banking and Finance, IRIS Books, Houston, Texas, 1987.

2. Al-Jarhi, Mabid Ali (1983) "A Monetary and Financial Structure for an Interest-Free Monetary Economy: Institutions, Mechanism and Policy", presented to Seminar on Monetary and Fiscal Economics, Islamabad, Jan., 1981, in Z. Ahmad, M. Iqbal and M.F. Khan, eds., Money and Banking in Islam, Center for Research in Islamic Economics, Jeddah, and the Institute of Policy Studies, Islamabad.

3. Al-Jarhi, Mabid Ali (1999), "Islamic Finance in the 21st Century: the Way Ahead," Inaugural Speech, The International Conference on Islamic Economics for the 21st Century, the Islamic Research and Training Institute, IRTI, and the International Islamic University, IIU, held in Kuala Lumpur, Malaysia, August.

4. Al-Jarhi, Mabid Ali (2003) "Islamic Banks \& Universal Banks: Need For Leveled Playing Field," A paper presented to the International Seminar on Islamic Banking: Risk Management, Regulation and Supervision, organized by: the Ministry Finance Indonesia, the Central Bank Indonesia and the Islamic Research and Training Institute (Member of Islamic Development Bank Group), Jakarta, Indonesia, September 30 - October 
2,.http:/ /www.iaie.net/mabid/ISLAMIC\%20\&\%20UNIVE RSAL\%20BANKS.pdf

5. Al-Jarhi, Mabid Ali (2007), Institutional Tawarruq as a Products of Ill Repute, Workshop on Tawarruq: A Methodological issue in Shari`ah-Compliant Finance, Harvard Law School \& London School of Economics February 1.

6. Al-Jarhi, Mabid Ali (2012), "proposed amendments to the Central Bank Law in Egypt," unpublished memo presented to the Economic Committee of Majless AlSha'ab.

7. The International Islamic Fiqh Academy (2009), resolutions of the 19th Meeting, Sharjah. http://www.fiqhacademy.org.sa/

8. The International Islamic Fiqh Academy (2012), resolutions of the 20 th Meeting, Algeria. http:/ / www.almeshkat.net/vb/attachment.php?s=81574 07334f3cd907bb484988dac983c\&attachmentid=11026\& $\underline{\mathrm{d}=1364070304}$ 